\title{
Advisable including glucosaminylmuramyldipeptide in Helicobacter pylori therapy: experience of ten-year investigation
}

\author{
M.R. Konorev ${ }^{1}$, S.V. Guryanova ${ }^{2,3}$, E.N. Tyshevich¹, R.A. Pavlyukov ${ }^{1}$, O. Yu. Borisova ${ }^{4}$ \\ ${ }^{1}$ Vitebsk State Medical University, Vitebsk, Belarus \\ ${ }^{2}$ Shemyakin and Ovchinnikov Institute of Bioorganic Chemistry RAS Moscow, Russian Federation \\ ${ }^{3}$ Peoples' Friendship University of Russia (RUDN University), Medical Institute, Moscow, Russian Federation \\ ${ }^{4}$ Moscow Research Institute of Epidemiology and Microbiology named after G.N. Gabrichevsky, \\ Moscow, Russian Federation
}

\begin{abstract}
Helicobacter pylori infection is a common bacterial infection in humans and is associated with peptic ulcer disease and chronic gastritis. The presence of natural resistance to some antibiotics in bacteria, as well as the appearance of primary and secondary resistance to antibacterial agents, complicates treatment and determines the search for new methods of therapy. The aim of this study was to evaluate the efficacy and safety of 10-year complex treatment of patients with duodenal ulcer associated with H.pylori, 136 patients (96 men, 40 women; mean age $45.8 \pm 14.8$ years; $18-65$ years). H.pylori was determined morphologically and by rapid urease test one day before the start of therapy, after 1, 6, 12 months, 2 years, 5 and 10 years. Patients of the first group received basic therapy: omeprazole $0.02 \mathrm{~g} 2$ times a day, clarithromycin $0.5 \mathrm{~g} 2$ times a day, amoxicillin $1 \mathrm{~g} 2$ times a day, for 10 days (OCA group $1 ; \mathrm{n}=98$ ). Patients of the second group, in addition to the basic therapy, took $1 \mathrm{mg}$ per day drug Licopid (group 2 OCAL; $\mathrm{n}=38$ ). At the 1st stage of the clinical study, 130 patients completed eradication therapy. Tracking completeness was $96 \%$. The frequency of H.pylori eradication after per protocol treatment: OCA - 83 \% (95 \% CI: 75 \%-91 \%), OCAL - $97 \%$ (95\% confidence interval (CI): $92 \%-100 \%$ ). The incidence of adverse reactions after treatment (per protocol): OCA - $26 \%$ (95 \% CI: 17-35 \%; nausea; $n=24)$, discontinued treatment - 5 \% (95 \% CI: $0.8 \%-10 \%$; diarrhea; $n$ = 5); OCAL - 3 \% (95 \% CI: $0.01 \%-8 \%$; nausea; $\mathrm{n}=1$ ), all were treated. Taking the drug Licopid $1 \mathrm{mg}$ (glucosaminyl muramyl dipeptide, JSC Peptek, Russia) as part of complex therapy contributed to the elimination of H.pylori and the absence of relapses for 2 years. Observation of patients in the next 5 and 10 years also showed the advantage of including the immunomodulator in therapy: a significant $15 \%$ decrease in H.pylori reinfection $(\mathrm{P}<0.05)$, a $23 \%$ decrease in the frequency of gastrointestinal adverse reactions $(\mathrm{P}<0.01)$, compared with a 10-day standard triple regimen without immunomodulatory therapy with glucosaminylmuramyl dipeptide. When using several antibiotics in H.pylori eradication therapy, not only pathogenic, but also commensal microorganisms are destroyed, the waste products of which are vital and maintain immune homeostasis, including through the NOD2 receptors of innate immunity. The effectiveness of the complex therapy of H.pylori infection can be explained by the fact that the drug Licopid compensates for the signal for innate immunity receptors that is missing due to the absence of commensals, providing an adequate immune response and preventing chronicity and recurrence of infection.

Key words: duodenal ulcer, Helicobacter pylori, Licopid, glucosaminyl muramyl dipeptide, eradication, recurrence, reinfection, immunomodulatory therapy
\end{abstract}

(C) Konorev M.R., Guryanova S.V., Tyshevich E.N., Pavlyukov R.A., Borisova O. Yu., 2020

This work is licensed under a Creative Commons Attribution 4.0 International License https://creativecommons.org/licenses/by/4.0/ 
Конорев М.Р. и др. Вестник РУДН. Серия: Медицина.2020. Т. 24. № 3. С. 269-282

Contribution of the authors. The authors declare an equal contribution to the preparation of the article.

Conflict of Interest Statement. The authors declare no conflict of interest.

Received 19.052020. Accepted 06.06.2020

For citation: Konorev M.R., Guryanova S.V., Tyshevich E.N., Pavlyukov R.A., Borisova O.Yu. Advisable including glucosaminylmuramyldipeptide in Helicobacter pylori therapy: experience of ten-year investigation. RUDN Journal of Medicine. 2020 Mar; 24 (3): 269—282. DOI: 10.22363/2313-0245-2020-24-3-269-282

\title{
Целесообразность включения глюкозаминилмурамилдипептида в терапию Helicobacter pylori: опыт десятилетнего наблюдения
}

\author{
М.P. Конорев ${ }^{1}$, С.В. Гурьянова ${ }^{2,3}$, Е.Н. Тышевич ${ }^{1}$, Р.А. Павлюков ${ }^{1}$, О.Ю. Борисова ${ }^{4}$ \\ ${ }^{1}$ Витебский государственный медицинский университет, г. Витебск, Беларусь \\ ${ }^{2}$ Федеральное государственное бюджетное учреждение науки «Институт биоорганической химии им. академиков \\ М.М. Шемякина и Ю.А. Овчинникова» Российской академии наук, г. Москва, Российская Федерация \\ ${ }^{3}$ Федеральное государственное автономное образовательное учреждение высшего образования «Российский универ- \\ ситет дружбы народов» Министерства науки и высшего образования Российской Федерации, Медицинский институт, \\ г. Москва, Российская Федерация \\ ${ }^{4}$ Московский НИИ эпидемиологии и микробиологии им. Г.Н. Габричевского, г. Москва, Российская Федерация
}

Аннотация. Инфекция Helicobacter pylori относится к распространенным бактериальным инфекциям человека и ассоциирована с язвенной болезнью и хроническим гастритом. Наличие у бактерии природной резистентности к некоторым антибиотикам, а также появление первичной и вторичной устойчивости к антибактериальным средствам осложняет лечение и обуславливает поиск новых способов терапии. Целью настоящего исследования явилась оценка эффективности и безопасности 10-летнего комплексного лечения 136 пациентов с язвой двенадцатиперстной кишки. Для идентификации H.pylori в двух группах использовали быстрый уреазный тест и морфологические исследования. Эндоскопическое обследование проводили за один день до начала терапии, через 1, 6, 12 месяцев, 2 года, 5 и 10 лет. Пациенты первой группы принимали базисную терапию: дважды в сутки омепразол по 0,02 г, кларитромицин 0,5 г 2 раза в сутки, амоксициллин 1 г 2 раза в сутки, в течение 10 дней (1 группа OKA; n=98). Пациенты второй группы в дополнение к базисной терапии в течение 10 дней принимали 1мг в день препарат Ликопид (2 группа ОКАЛ; n=38). На 1-ом этапе клинического исследования закончили эрадикационную терапию 130 пациентов. Полнота отслеживания составила 96 \%. Частота эрадикации H.pylori после лечения per protocol: OKA - 83 \% (95 \% ДИ: 75 \%-91 \%), ОКАЛ - 97 \% (95 \% доверительный интервал (ДИ): 92 \%-100 \%). Частота развития побочных реакций после лечения (per protocol): OKA - 26 \% (95 \% ДИ: 17-35 \%; тошнота; n=24), прекратили лечение - 5 \% (95 \% ДИ: 0,8 \%-10 \%; диарея; n=5); ОКАЛ - 3 \% (95 \% ДИ: 0,01 \%-8 \%; тошнота; n=1), все прошли лечение. Прием препарата Ликопид 1 мг (глюкозаминилмурамилдипептид, АО Пептек, Россия) в составе комплексной терапии способствовал элиминации H.pylori и отсутствию рецидивов в течение 2 лет. Наблюдение за пациентами в последующие 5 и 10 лет также показало преимущество включения иммуномодулятора в терапию: достоверное снижение на 15 \% реинфекции H.pylori $(\mathrm{P}<0,05)$, снижение частоты побочных реакций со стороны ЖКТ на $23 \%(\mathrm{P}<0,01)$, по сравнению с 10 -ти дневной стандартной тройной схемой без иммуномодулирующей терапии глюкозаминилмурамилдипептидом. При использовании нескольких антибиотиков в эрадикационной терапии H.pylori уничтожаются не только патогенные, но и комменсальные микроорганизмы, продукты жизнедеятельности которых являются жизненно необходимыми и поддерживают иммунный гомеостаз, в том числе через NOD2 рецепторы врожденного иммунитета. Эффективность 
комплексной терапии инфекции H.pylori может быть объяснена тем, что препарат Ликопид компенсирует недостающий в связи с отсутствием комменсалов сигнал для рецепторов врожденного иммунитета, обеспечивая адекватный иммунный ответ и препятствуя хронизации и рецидивированию инфекции.

Ключевые слова: язва двенадцатиперстной кишки, Helicobacter pylori, ликопид, глюкозаминилмурамилдипептид, эрадикация, рецидив, реинфекция, иммуномодулирующая терапия

Вклад авторов. Авторы заявляют о равном вкладе в подготовке статьи.

Заявление о конфликте интересов. Авторы заявляют об отсутствии конфликта интересов.

Для цитирования: Конорев М.Р., Гурьянова С.В., Тышевич Е.Н., Павлюков Р.А., Борисова О.Ю. Целесообразность включения глюкозаминилмурамилдипептида в терапию Helicobacter pylori: опыт десятилетнего наблюдения. // Вестник Российского университета дружбы народов. Серия: Медицина. 2020. Т. 24. o 3. С. 269—282. DOI: 10.22363/2313-02452020-24-3-269-282

Since the identification of Helicobacter pylori in 1982, and much has been learned about this bacterium, it remains one of the most common bacterial infection in humans [1- 4]. The bacterium causes a diverse pathology of the upper gastrointestinal tract from H.pylori-induced gastroduodenitis and H.pylori-associated dyspepsia to gastroduodenal ulcer, MALT lymphoma and gastric cancer. This requires appropriate anti- Helicobacter therapy [2, 5]. H.pylori eradication is a first-line therapy for H.pylori-infected patients with dyspepsia (Kyoto Global Consensus on Helicobacter pylori; Regulation 9). H.pylori-infected patients should be offered eradication therapy unless otherwise stated (Kyoto Global Consensus on Helicobacter pylori; Regulation 17) [5]. Eradication of bacteria is also necessary to control complications and reduce the number of relapses of gastroduodenal ulcer associated with H.pylori infection. The clinical effect of successful H.pylori eradication is manifested by a sharp drop in the recurrence rate of this disease after elimination of the bacterium [6].

The presence of natural resistance to some antibiotics in bacteria, as well as the appearance of primary and secondary resistance to antibacterial agents, complicates treatment and determines the search for new methods of therapy. This is reflected in current international guidelines for H.pylori eradication, which presents not only the first-line treatment regimens, but also various other treatment regimens taking into account the clarithromycin-resistant H.pylori strains in the region (Table 1 ).

Recommended regimens for eradication of Helicobacter pylori (Consensus Ma-Astricht V, 2017) [2]

\begin{tabular}{|c|}
\hline Standard triple therapy: PPI + clarithromycin + amoxicillin (10-14 days) \\
\hline Standard quadrotherapy with bismuth: PPI + tetracycline + metronidazole + de-nol (10-14 days) \\
\hline Sequential therapy: $\mathbf{5 - 7}$ days - PPI + amoxicillin, then 5-7 days - PPI + clarithromycin + metronidazole / tinidazole \\
\hline Concomitant therapy or quadrotherapy without bismuth: PPI + amoxicillin + clarithromycin + metronidazole / tinidazole (10-14 days) \\
\hline Hybrid therapy: PPI + amoxicillin 14 days + from $\mathbf{8}$ to 14 days - clarithromycin + metronidazole / tinidazole \\
\hline First line starting circuits: standard triple therapy, standard bismuth quadrotherapy \\
\hline
\end{tabular}

Note: PPI is a proton pump inhibitor. 
Конорев М.Р. и др. Вестник РУДН. Серия: Медицина.2020. Т. 24. № 3. С. 269—282

Рекомендуемые схемы для эрадикации Helicobacter pylori (Консенсус Маастрихт V, 2017 г.) [2]

Стандартная тройная терапия: ИПП + кларитромицин + амоксициллин (10-14 дней)

Стандартная квадротерапия с висмутом: иПП + тетрациклин + метронидазол + Де-нол (10-14 дней)

Последовательная терапия: 5-7 дней - ИПП + амоксициллин, затем 5-7 дней - ИПП + кларитромицин + метронидазол/ тинидазол

Сопутствующая терапия или квадротерапия без висмута: ипП + амоксициллин + кларитромицин + метронидазол/тинидазол (10-14 дней)

Гибридная терапия: ИПП + амоксициллин 14 дней + с 8 по 14 день - кларитромицин + метронидазол/тинидазол

Стартовые схемы первой линии: стандартная тройная терапия, стандартная квадротерапия с висмутом

\section{Quadrotherapy for the CIS countries}

Quadrotherapy for the CIS countries (taking into account the growth of H.pylori resistance to antibiotics and the presence of fast metabolizers (60-70 \%) in the population of the Russian Federation; Megraud Francis "Approaches to the treatment and diagnosis of H.pylori. European Register data” 2015) includes Omeprazole $0.02 \mathrm{~g}$ x 3 times a day, Amoxicillin $1.0 \mathrm{~g}$ x 3 times a day, Josamycin $1.0 \mathrm{~g}$ x 2 times a day, De-nol $0.24 \mathrm{~g} \mathrm{x}$ 2 times a day. The duration of therapy is 10-14 days.

Measures to increase the effectiveness of standard triple therapy taking into account the growth of H.pylori resistance to antibiotics (Recommendations of the Russian Gastroenterological Association, 2018): Omeprazole 0.04 g x 2 times a day, Clarithromycin 0.5 g x 2 once a day, Amoxicillin 1.0 g x 2 times a day, De-nol 0.24 g x 2 times a day. The duration of therapy is 10-14 days. Addition to the standard triple therapy of probiotic strains of Bifidobacterium and Lactobacillus [7].

It is very difficult to reach H.pylori eradication. In most patients, a year after successful eradication, reinfection of $H$.pylori occurs within the next 10 years $[8,9]$. In the Russian Federation and countries of Eastern Europe, H.pylori reinfection exceeds $5 \%$ per year, in Western Europe and the USA - less than $3 \%$ per year $[3,10]$. In order to optimize standard therapy different approaches are investigated, for example the usage of probiotics [2, 11, 12].

This is reflected in Provisions 9 and 10 of the Consensus of Maastricht V [2], which are formulated as follows: certain probiotics are effective in reducing gastrointestinal side effects caused by H.pylori eradication therapy. Specific strains should only be selected on the basis of proven clinical efficacy (Consensus Maastricht V; Regulation 9). Certain probiotics may have a beneficial effect on $H$.pylori eradication (Consensus Maastricht V; Regulation 10). It is believed that probiotic strains, in particular Lactobacillus, decrease the activity of bacterial urease, the motility of H.pylori and the adhesion of H.pylori to gastric epithelial cells [7].

The concept is formulated that the immunomodulating effect plays a significant role in the mechanism of antimicrobial action of pro-biotics [13]. The origin of the immunomodulator and its influence on the mucosa are the main issues $[14,15]$. It is known that glucosaminyl muramyl dipeptide (GMDP) modulate immune answer via NOD2 receptors and YB1 protein $[16,17]$ and is effective in the therapy of infections [18-20], allergy[21, 22], psoriasis [23], correction of cytopenia [24] and microbiocenosis [25]. The positive effect of Licopid 10mg on the elimination of H.pylori was investigated earlier [26, 27] correlates with another dosage of this drug $-1 \mathrm{mg}$.

During the first stage of this randomized prospective comparative clinical study of the effectiveness of $H$. pylori elimination in standart triple therapy with addition of GMDP 1mg was carried out. During the second stage of this investigation the frequency of relapse and reinfection of Helicobacter pylori was measured. 


\section{Material and methods}

This study was approved by the Ethics Committee of the Vitebsk State Medical University (Vitebsk, Belarus) and was carried out during 2000-2020 years. Prior to the start of the study, informed consent was obtained from all patients to participate in the study and the processing of personal data.

The first stage of a prospective, randomized, comparative clinical study was conducted to evaluate the efficacy and safety of H.pylori eradication during standard triple therapy with Licopid.

Inclusion criteria: the presence of H.pylori- associated duodenal ulcer (DU).
Exclusion criteria: patients using antibacterial drugs less than a month before the start of eradication therapy or FEGDS research.

Eradication therapy was performed in 136 patients (96 men, 40 women; mean age $45.8 \pm 14.8$ years (mean \pm SD; 18 - 65 years) with a duodenal ulcer associated with $H$. pylori (Table 2). Patients were divided by a randomized lottery drum method into 2 groups according to treatment protocols: omeprazole $0.04 \mathrm{~g}$ / day, clarithromycin $1 \mathrm{~g}$ / day, amoxicillin $2 \mathrm{~g}$ / day for 10 days (OCA; $\mathrm{n}=98$ ); omeprazole $0.04 \mathrm{~g}$ / day, clarithromycin $1 \mathrm{~g}$ / day, amoxicillin $2 \mathrm{~g}$ / day, Lycopid $0.001 \mathrm{~g} /$ day for 10 days (OCAL; $\mathrm{n}=38$ ).

Patient profile

\begin{tabular}{|c|c|c|c|c|c|}
\hline Treatment Protocols & $\begin{array}{l}\text { Number of } \\
\text { Patients }\end{array}$ & \multicolumn{2}{|c|}{$\begin{array}{c}\text { Gender } \\
\text { m f }\end{array}$} & Age (years) & $\begin{array}{c}\text { Disease duration } \\
\text { (years) }\end{array}$ \\
\hline $\begin{array}{c}\text { Omeprazole } 0.04 \mathrm{~g} / \text { day } \\
\text { Clarithromycin } 1 \mathrm{~g} / \text { day } \\
\text { Amoxicillin } 2 \mathrm{~g} / \text { day }\end{array}$ & 98 & 69 & 29 & $48,3+14,2$ & $8,7+3,9$ \\
\hline $\begin{array}{c}\text { Omeprazole } 0.04 \mathrm{~g} / \text { day } \\
\text { Clarithromycin } 1 \mathrm{~g} / \text { day } \\
\text { Amoxicillin } 2 \mathrm{~g} / \text { day } \\
\text { Lycopid } 0.001 \mathrm{~g} / \text { day }\end{array}$ & 38 & 27 & 11 & $37,2+14,3$ & $8,3+3,9$ \\
\hline Total & 136 & 96 & 40 & $45,8+14,8$ & $8,6+4,1$ \\
\hline
\end{tabular}

Характеристика пациентов

Таблица 2

\begin{tabular}{|c|c|c|c|c|c|}
\hline Протоколы лечения & $\begin{array}{c}\text { Количество } \\
\text { пациентов }\end{array}$ & \multicolumn{2}{|c|}{$\begin{array}{c}\text { Пол } \\
\text { муж жен }\end{array}$} & $\begin{array}{l}\text { Возраст } \\
\text { (годы) }\end{array}$ & $\begin{array}{c}\text { Длительность } \\
\text { заболевания (годы) }\end{array}$ \\
\hline $\begin{array}{c}\text { Омепразол 0,04 г/сут } \\
\text { Кларитромицин } 1 \text { г/сут } \\
\text { Амоксициллин } 2 \text { г/сут }\end{array}$ & 98 & 69 & 29 & $48,3+14,2$ & $8,7+3,9$ \\
\hline $\begin{array}{c}\text { Омепразол 0,04 г/сут } \\
\text { Кларитромицин } 1 \text { г/сут } \\
\text { Амоксициллин } 2 \text { г/сут } \\
\text { Ликопид 0,001 г/сут }\end{array}$ & 38 & 27 & 11 & $37,2+14,3$ & $8,3+3,9$ \\
\hline Всего & 136 & 96 & 40 & $45,8+14,8$ & $8,6+4,1$ \\
\hline
\end{tabular}

The study completed 130 patients. Six people (4.4\%) were excluded from the general group (5 people from the OCA group and 1 person from the OCAL group) due to the lack of data on the diagnosis of H.pylori or the cessation of medication. The completeness of tracking was $95.6 \%$.
In the second stage were included 113 patients aged from 18 till 65 which successfully passed first stage (44.1 \pm 13.5 years, 81 men and 32 women).

Over 10 years, 11 people (9.7\%; $95 \%$ CI: 4.2$15.2 \%)$ were excluded from the general group due to the refusal of repeated endoscopic examinations 
with the diagnosis of H.pylori (8 people) or on their own desire (3 people). The completeness of tracking up to 2 years was 108 (95.6 \%; 95 \% CI: 91.8-99.4\%) people, from 2 to 5 years old - 104 (92.0\%; $95 \%$ CI: $87.0-97.0 \%$ ) of a person, from 6 to 10 years old - 102 (90.3\%; 95 \% CI: 84.8-95.8 \%) of a person.

In a randomized trial 113 patients had the following treatment: 0.04 g omeprazole, 1.0 g clarithromycin, 2.0 g amoxicillin per day dyring 10 days (group OCA ; $\mathrm{n}=77$ ). patients from the the second group received 0.04 g omeprazole, 1.0 g clarithromycin, $2.0 \mathrm{~g}$ amoxicillin and $0.001 \mathrm{~g}$ Lycopid per day (group OCAL ; $\mathrm{n}=36$ ).

The tissue investigation of the duodenum was carried out by standard systematization and methods $[28,29]$. To identify areas of gastric metaplasia (GM) of duodenum, an additional staining of histological sections of the mucous membrane of duodenal ulcer was performed with Chic -alcian blue (Serva) $\mathrm{pH} 1.0$ and 2.5 [30].

Intestinal metaplasia and all cell- and tissuemorphologic characteristics were assessed using a visual analogue scale [31-33] according to the histological section of the Houston modification of the Sydney classification.

During the histological examination of the duodenal mucosa standard indicators were taken into account [30, 34]. Diagnostics of H.pylori was carried out by Romanovsky-Giemsa stain; assessment using a standard visual-analogue scale [35] and a quick urease test (standard test systems Jatrox ${ }^{\circledR}$-Hp-Test, Rohm Pharma, Germany; HELPIL $®$ and AMA RUT Pro®, LLC “AMA”, Russia) [36].

For statistical processing the program «STATISTICA 10.0 » and t-test were used. If the distribution of the variable was not normal, the Shapiro-Wilk test was used. The Mann-Whitney U-test was used to evaluate the differences between two independent small samples by the level of the trait, measured quantitatively. Patient age was presented as mean \pm standard deviation (SD). $\mathrm{P}$ levels $<0.05$ were considered significant [37].

\section{Results and its discussion}

The results of the first stage of a prospective, randomized, comparative clinical study are represented in the Table 3.

The frequency of H.pylori eradication depending on the prescribed treatment (ITT) and the actual treatment received (PP): OCA - 78.6 \% (95 \% CI: $70.4 \%$-86.8 \%) and $82.8 \%$ (95 \% CI: $75.1 \%$-90.5 \%), OCAL - $94.7 \%$ (95 \% CI: $87.5 \%-100 \%$ ) and $97.3 \%$ (95 \% CI: $91.7 \%$ $-100 \%)$ respectively. The incidence of adverse reactions (PR) depending on the prescribed treatment and the actual treatment received: OCA - $24.5 \%$ (95 \% CI: $15.9 \%-33.1 \%$ ) and $25.8 \%$ (95 \% CI: $16,8-34.8 \%$; nausea; $n=24)$, discontinued treatment - $5.1 \%(95 \%$ CI: $0.7 \%-9.5 \%$ ) and $5.4 \%$ (95 \% CI: $0.8 \%-10.0 \%$; diarrhea; $n=5)$; OCAL - $2.6 \%$ (95 \% CI: $0.01 \%$-7.7 \%) and $2.7 \%$ (95 \% CI: $0.01 \%-7.8 \%$; nausea; $n=1)$, discontinued treatment - $0 \%$.

Reception of Lycopid $0.001 \mathrm{~g}$ / day during a 10-day three-component anti-bacterial treatment significantly increased H.pylori eradication by $16.0 \%$ (according to ITT) and $14.5 \%$ (according to PP; respectively $x^{2}=3.87$; $\mathrm{P}=0.0492$ and $\chi 2=4.0 ; \mathrm{P}=0.0455$ ), with a significant decrease in PR frequency by $2.5 \%$ (according to ITT) and $2.7 \%$ (according to PP; respectively, $\chi 2=2.38$; $\mathrm{P}=0.0115$ and $\chi^{2}=6.56 ; \mathrm{P}=0.0105$ ) and the complete completion of the course of therapy by all patients.

Results of a prospective randomized comparative clinical study of the frequency of $H$. pylori eradication and adverse effects depending on the prescribed treatment (stage I).

\begin{tabular}{|c|c|c|c|}
\hline Treatment Protocols & $\mathbf{n}$ & Eradication \% (95\% Cl) & Adverse Effects \% (95 \% Cl) \\
\hline $\begin{array}{l}\text { Omeprazole } 0.04 \mathrm{~g} / \text { day } \\
\text { Clarithromycin } 1 \mathrm{~g} / \text { day } \\
\text { Amoxicillin } 2 \mathrm{~g} / \text { day } 98\end{array}$ & $\begin{array}{l}98 \\
93\end{array}$ & $\begin{array}{l}\text { ITT 78,6 }(70,4-86,8) \\
\text { PP } 82,8(75,1-90,5)\end{array}$ & $\begin{array}{c}\text { ITT } 24,5(15,9-33,1) \\
\text { PP } 25,8(16,8-34,8) \\
\text { stopped treatment } \\
\text { ITT } 5,1(0,7-9,5) \\
\text { PP } 5,4(0,8 \%-10,0)\end{array}$ \\
\hline
\end{tabular}


Результаты проспективного рандомизированного сравнительного клинического исследования частоты эрадикации H.pylori и побочных реакций в зависимости от назначенного лечения (I этап)

\begin{tabular}{|c|c|c|c|}
\hline Протоколы лечения & $\mathbf{n}$ & $\begin{array}{l}\text { Эрадикация } \\
\text { \% (95 \% ДИ) }\end{array}$ & $\begin{array}{c}\text { Побочные реакции } \\
\text { \% (95 \% ДИ) }\end{array}$ \\
\hline $\begin{array}{c}\text { Омепразол 0,04 г/сут } \\
\text { Кларитромицин } 1 \text { г/сут } \\
\text { Амоксициллин } 2 \text { г/сут }\end{array}$ & $\begin{array}{l}98 \\
93\end{array}$ & $\begin{array}{l}\text { ITT 78,6 (70,4-86,8) } \\
\text { PP 82,8 }(75,1-90,5)\end{array}$ & $\begin{array}{c}\text { ITT 24,5 (15,9-33,1) } \\
\text { PP 25,8 (16,8-34,8) } \\
\text { прекратили лечение } \\
\text { ITT 5,1 (0,7-9,5) } \\
\text { PP 5,4 (0,8 \%-10,0) }\end{array}$ \\
\hline
\end{tabular}

After 1 months (end of stage 1 of the study) after eradication therapy, according to the morphological method and rapid urease test, H.pylori was absent in the stomach and in the sections of the mucous membrane of the mucous membrane of the duodenal bulb in all patients included in the next phase of the clinical study (table 4).
Relapse of H.pylori infection 6 months after per protocol treatment: OCA - 3.9 \% (95 \% CI: 0.01-8.3\%; $\mathrm{n}=3$ ), OCAL - $0 \%$. Relapse of H.pylori infection 1 year after per protocol treatment: OCA - $5.2 \%$ (95\% CI: $0.2-10.2 \% ; n=4)$, OCAL - $0 \%$ (Table 4). As follows from the results of the study, GMDP eliminates H.pylori during 12 and 24 months and was decreased after 5 and 10 years.

Diagnosis of $H$. pylori after 1 months, 6 months, 1 year, 2 years, 5 years and 10 years after treatment

\begin{tabular}{|c|c|c|c|c|c|c|c|c|c|c|}
\hline Groups & \multicolumn{10}{|c|}{ Helicobacter pylori } \\
\hline OCA & 77 & - & 3 & 4 & 72 & 9 & 68 & 13 & 67 & 23 \\
\hline OCAL & 36 & - & - & - & 36 & - & 36 & 1 & 35 & 2 \\
\hline
\end{tabular}

Диагностика H.pylori через 1 месяца, 6 месяцев, 1 год, 2 года, 5 лет и 10 лет после лечения

\begin{tabular}{|c|c|c|c|c|c|c|c|c|c|c|}
\hline Группы & \multicolumn{10}{|c|}{ Helicobacter pylori } \\
\hline ОКАЛ & 36 & - & - & - & 36 & - & 36 & 1 & 35 & 2 \\
\hline
\end{tabular}


The frequency of H.pylori reinfection 2 years after per protocol treatment: OCA - $12.5 \%$ (95\% CI: 4.8-20.2 \%; $\mathrm{n}=9$ ), OCAL - $0 \%$. The frequency of H.pylori reinfection 5 years after per protocol treatment: OCA - 19.1 \% (95 \% CI: 9.7-28.5 \%; $\mathrm{n}=13$ ), OCAL - $2.8 \%$ (95 \% CI: 0 , 01-8.3 \%; $n=$ 1). The frequency of $H$. pylori reinfection 10 years after per protocol treatment: OCA - 34.3\% (95\% CI: $22.8-45.8 \%$; $n=23)$, OCAL - $5.7 \%$ (95 \% CI: 0, 01-13.5 \%; $n=2$; Table 3). Thus, in patients taking Licopid at a dose of $1 \mathrm{mg}$ per day together with antiHelicobacter pylori therapy (the OCAL group), there was no H.pylori reinfection 2 years after per protocol treatment compared to the 10-day three-component treatment protocol without Lycopid. At the second stage of the study, it was also found that patients who took Licopid at the above dose together with three-component anti-bacterial therapy (OCAL group) had a significantly low frequency of $H$. pylori reinfection for 5 years $\left(\mathrm{X}^{2}=\right.$ 4.33; $\mathrm{P}=0.0375)$ and 10 years $(\mathrm{X}=6.73 ; \mathrm{P}=0.0095)$.

The choice of patients with localization of an ulcer in the duodenal bulb (duodenal ulcer) as participants in a clinical study was based on the fact that, with duodenal ulcer of onion localization, a maximum degree of contamination of H.pylori gastric mucosa was observed (99.0\%) [38] and sections of gastric metaplasia of the mucous membrane of the duodenal bulb (87.8 \%) [39].

The choice of Licopid as an immunomodulator therapy in the 10-day H.pylori eradication scheme was consistent with the concept of an "ideal” immunomodulator and was based on three main criteria, according to current scientific research data [40]:

The first criterion includes the presence of $\mathrm{N}$-acetyl-glucosaminyl-N-acetylmuramyl dipeptide. One of the reasons for the ineffectiveness of eradication therapy is the transition of H.pylori to metabolically inactive forms (coccoid and U-form) that are resistant to antibiotics. It was previously shown that glucosaminyl muramil dipeptide promoted the release of Mycobacterium tuberculosis from the dormant form, which, apparently, determines the effectiveness of Licopid therapy [41]. Similarly, it was previously shown that NOD1 and NOD2 receptor activation promotes the elimination of H.pylori [42, 43]. The active substence of Lycopide, $\mathrm{N}$-acetylglucosaminyl-N-acetylmuramyl dipeptide (GMDP, glucosaminyl muramyl dipeptide), is the main complete repeating structural unchanged fragment of the cell wall of almost all known bacteria, a ligand of NOD2 receptors.

According to the second criterion for "ideal" immunomodulator it is necessary to activate immune system through T helper 1 lymphocytes. It was shown that activation immune answer through $\mathrm{T}$ helper 1 lymphocytes is essential for successful treatment H. pylori [44-47]. GMDP fully complies with the second criterion - its influence on the balance T helper $1 / \mathrm{T}$ helper 2 shift towards T helper 1 has been proven $[21,22,48]$.

By the third criterion an "ideal" immunomodulator has a bacterial, probiotic origin. According to Regulation 9 of Working Group 5 (Consensus Maastricht V) [2] and based on 14 meta-analyzes of RCTs (2007-2019) [4962], which combined 259 RCTs with 41727 patients, the addition of Lactobacillus strains optimizes therapy and decreases adverse effects.

These meta-analyzes found that specific strains of Lactobacillus or several probiotic strains increase eradication of H.pylori by $8.1 \%$ and reduce the number of adverse reactions when using the probiotic 14 days before eradication therapy or during eradication therapy. Bifidobacterium and Saccharomyces boulardii did not affect the level of eradication during anti- Helicobacter therapy $[58,62]$. The use of specific strains of probiotics (Lactobacillus bulgaricus, Lactobacillus acidophilus, Lactobacillus casei DN-114001, Lactobacillus gasseri, and Bifidobacterium infantis 2036) during eradication therapy can be considered as an option to increase the level of H.pylori eradication, especially when the antibiotic is not effective $[63,68]$. The effect of probiotics on the reduction of adverse reactions during eradication therapy has been proven [62]. A significant increase in the eradication of H.pylori by $17 \%$ was found using mainly specific strains of Lactobacillus. When multicomponent probiotics were used as adjuvant therapy, eradication increased by only $2.8 \%$ [54]. Monotherapy with probiotics using specific strains of Lactobacillus led to significant ( $\mathrm{P}<0.001)$, compared with placebo, eradication of H.pylori in $16 \%$ of patients, using multicomponent probiotics (which included Lactobacillus strains) in $14 \%$ of patients [63]. 
Interestingly, that GMDP was for identified the first time as a fragment of Lactobacillus bulgaricus cell wall [64] and thus its beneficial effect in H.pylori therapy is consistent with the data of the above studies.

Based on the data obtained, it can be concluded that therapy with the immunomodulator Licopid in a 10-day H.pylori eradication scheme demonstrated an encouraging result. GMDP maintaines the long term (2, 5 and 10 years) eradication of H.pylori in $100 \%, 98 \%$ and in $95 \%$ of cases. The reinfection of H.pylori after 5 years of the treatment is observed in $32 \%-91,4 \%$ cases $[8,9,65]$. Thus, the method for optimizing $H$. pylori therapy proposed in this research is in demand and has practical significance.

\section{Conclusions}

GMDP at a dose of $0.001 \mathrm{~g}$ per day during 10-day three-component anti-Helicobacter therapy significantly increased H.pylori eradication by $16 \%$ (according to ITT; $\chi 2=3,87 ; \mathrm{P}=0.0492$ ) and by $14.5 \%$ (according to $\left.\mathrm{PP} ; \chi^{2}=4.0 ; \mathrm{P}=0.0455\right)$, with a significant decrease in the frequency of adverse reactions from the gastrointestinal tract by $2.5 \%$ (according to ITT; $x^{2}=2.38 ; P=0.0115$ ) and $2.7 \%$ (according to PP; $x 2=$ $6.56 ; \mathrm{P}=0.0105$ ) and the completion of the course of therapy by all patients. GMDP maintain the absence of H.pylori in $100 \%$ during 2 years, in $98 \%$ after 5 years and in $95 \%$ after 10 years after treatment.

Triple antibiotic eradication therapy of $H$. pylori, eliminates both pathogenic and commensal microorganisms, the waste products of which are vital and maintain immune homeostasis, including via NOD2 receptors of innate immunity. The success of the complex H.pylori eradication treatment can be explained by the compensatory effect of the GMDP for the missing signal from commensals for innate immunity receptors, providing an adequate immune response and preventing chronicity and recurrence of the infection.

\section{References}

1. Malfertheiner P., Megraud F., O’Morain C.A., et al. Management of Helicobacter pylori infection - the Maastricht-IV / Florence Consensus Report. Gut. 2012; 61: 646-664. doi:_10.1136/ gutjnl-2012-302084

2. Malfertheiner P., Megraud F., O’Morain C.A., et al. Management of Helicobacter pylori infection - the Maastricht V / Florence Consensus Report. Gut. 2017; 66: 6-30. doi: 10.1136/gutjnl-2016-312288

3. Hunt R., Xiao S.D., Megraud F., et al. Helicobacter pylori in developing countries. World Gastroenterology Organisation Global Guideline. J. Gastrointestin. Liver Dis. 2011; 20(3): 299-304. doi: 10.1097/MCG.0b013e31820fb8f6

4. Marshall B.J. Warren J.R. Unidentified curved bacilli on gastric ileum in active chronic gastritis. Lancet. 1983; 1: 1273-1275.

5. Sugano K., Tack J., Kuiperset E.J. et al. Kyoto global consensus report on Helicobacter pylori gastritis. Gut. 2015; 64(9): 13531367. doi: 10.1136/gutjnl-2015-309252

6. Hopkins R.J. Current FDA-approved treatments for Helicobacter pylori and the FDA approval process. Gastroenterology. 1997; 113(6, Suppl): S126-30.

7. Ivashkin V.T., Maev I.V., Lapina T.L. et al. Clinical guidelines of the Russian Gastroenterological Association for the diagnosis and treatment of Helicobacter pylori infection in adults. Grew up. Gastroenterol. hepatol. coloproctol. 2018; 28 (1): 55-70.

8. Minushkin O.N., Osokina A.P., Shuleshova A.G. and others. Long-term results of successful eradication of Nonlicobacter pylori in patients with duodenal ulcer. Kremlin medicine. Clinical Bulletin. 2012; 1: 123-126. (in Russian)

9. Burakov I.I. Results of long-term observation of patients with peptic ulcer disease associated with Helicobacter pylori after eradication of the microorganism. Experiment. and a wedge. Gastroenterol. 2002; 3: 45-48. (in Russian)

10. Hu Y., Wan J.-H., Li X.-Y. et al. Systematic review with metaanalysis: the global recurrence rate of Helicobacter pylori. Aliment. Pharmacol. Ther. 2017; 46: 773-779. doi: 10.1111/apt.14319

11. Lionetti E., Indrio F., Pavone L., et al. Role of probiotics in pediatric patients with Helicobacter pylori infection: a comprehensive review of the literature. Helicobacter. 2010; 15(2): 79-87. doi: 10.1111/j.1523-5378.2009.00743.x

12. O’Connor A. et al. Treatment of Helicobacter pylori infection 2019. Helicobacter. 2019; 24(Suppl.1): e12640. doi: 10.1111/ hel.12640

13. Gill H.H., Prasad J. Probiotics, immunomodulation and health benefits. Adv. Exp. Med. Biol. 2008; 606: 423-454.

14. Pinegin B.V., Andronova T.M. Some theoretical and practical issues of the clinical use of the immunomodulator lycopid. Immunologiya.1998; 4: 60-63. (in Russian)

15. Guryanova S.V., Khaitov R.M. Glucosaminylmuramyldipeptide - GMDP: effect on mucosal immunity (on the issue of immunotherapy and immunoprophylaxis). Immunologiya. 2020; 41 (2): 174-83. DOI: 10.33029/0206-4952-2020-41-2-174-183 (in Russian)

16. Meshcheryakova E., Makarov E., Philpott D., Andronova T., Ivanov V. Evidence for correlation between the intensities of 
adjuvant effects and NOD2 activation by monomeric, dimeric and lipophilic derivatives of $\mathrm{N}$-acetylglucosaminy $\mathrm{N}$-acetylmuramyl peptides. Vaccine. 2007; 25: 4515-20.

17. Laman A.G., Lathe R., Shepelyakovskaya A.O., Gartseva A., Brovko F.A., Guryanova S., Alekseeva L., Meshcheryakova E.A., Ivanov V.T. Muramyl peptides activate innate immunity conjointly via YB1 and NOD2. Innate Immunity. 2016. T. 22. № 8. C. 666-673. DOI: 10.1177/1753425916668982

18. Krasheninnikov A.E., Matveev A.V., Andronova T.M., Guryanova S.V., Shilova N.V., Kozlov I.G. Safety of using the preparation "LICOPID ${ }^{\circledR}$ " in opinion of experts in various specialities. Perm Medical Journal. 2019.Vol. 36. No. 2. P. 81-92. (in Russian) DOI: 10.17816/pmj36281-92

19. Guryanova S.V. Antibiotic resistance: ligands of innate immunity take the challenge. Allergy. 2018. T. 73. № S105. C. 581.

20. Abramashvili Yu. G., Kolesnikova N.V., Borisova O. Yu., Guryanova S.V. Low molecular weight bioregulator of bacterial origin in condylomatosis therapy optimization. RUDN Journal of Medicine. 2020 Mar; 24 (2): 163-167. DOI:10.22363/23130245-2020-24-2-163-167

21. Kozlov I.G., Guryanova S.V., Kolesnikova N.V., Andronova T.M. Muramyl peptides and other agonists of innate immunity receptors in the treatment of allergic diseases. Rossiyskiy allergologicheskiy zhurnal. 2015; 5: 59-67. (in Russian)

22. Kozlov I.G., Kolesnikova N.V., Voronina E.V., Guryanova S.V., Andronova T.M. Glucosaminylmuramyl dipeptide and other innate immunity receptor agonists in the pathogenetic treatment of allergic diseases. Allergologiya and immunologiya. 2013; 14 (4): 281-7. (in Russian)

23. Guryanova S., Udzhukhu V., Kubylinsky A. Pathogenetic therapy of psoriasis by muramyl peptide. Frontiers in Immunology. 2019. T. 10. № JUN. C. 1275. DOI: 10.3389/fimmu.2019.01275

24. Manapova E.R., Fazylov V. Kh., Guryanova S.V. cytopenia and their correction in antiviral therapy of chronic hepatitis $\mathrm{C}$ in patients with genotype 1. Problems of Virology. 2017; 62(4):174-8. DOI: 10.18821/0507-4088-2017-62-4-174-178

25. Guryanova S.V., Borisova O.Yu., Kolesnikova N.V., Lezhava N.L., Kozlov I.G., Gudima G.O. The effect of muramyl peptide on the microbial composition of the microfl ora of the oral cavity. Immunologiya. 2019; 40 (6): 34-40. DOI: 10.24411/0206-49522019-16005. (in Russian)

26. Konorev M.R. The influence of lycopid on the persistence of Helicobacter pylori in the gastric mucosa of patients with chronic gastritis. Immunopathology, allergology, infectology. 2004; 2: 33-34. (in Russian)

27. Konorev M.R. Use of the immunopotentiator N-acetyl-glucosamine-N-acetyl-muramyl dipeptide during triple anti-Helicobacter pylori therapy. Ter Arkh. 2012; 84(12): 65-69. (in Russian)

28. Tytgat G.N. The Sydney system, endoscopic division: endoscopic appearance in gastritis. J. Gastroenterol. Hepatol. 1991; 6(3): 223-234.
29. Aruin L.I., Grigoriev P.Ya., Isakov V.A., Yakovenko E.P. Chronic gastritis. Amsterdam, 1993: 3-362.

30. Konorev M.R., Litvyakov A.M., Krylov Yu.V., Matveenko M.E. Chronic duodenitis. Minsk: Doctor Design LLC, 2003.

31. Price A.B. The Sydney system: Histological division. J. Gastroenterol. Hepatol. 1991; 6(3): 209-222.

32. Dixon M. et al. Classification and grading of gastritis. Am. J. Surg. Pathol. 1996; 20: 1161-1181.

33. Kido M., Tanaka J., Aoki N., et al. Helicobacter pylori promotes the production of thymic stromal lymphopoietin by gastric epithelial cells and induces dendritic cell-mediated inflammatory $\mathrm{Th}_{2}$ responses. Infect. Immun. 2010; 78(1): 108-114.

34. Chang C., Pan S., Lien Gi., et al. Investigation of the extent of gastric metaplasia in the duodenal bulb by using methylene blue staining. J.Gastroenterol.Hepatol. 2001; 16(7): 729-739.

35. Aruin L.I., Kapuller L.L., Isakov V.A. Morphological diagnosis of diseases of the stomach and intestines. M .: Triada-X, 1998: 13-496.

36. Konorev M.R., Matveenko M.E., Krylov A.Yu. et al. Rapid urease test Helpil for the diagnosis of Helicobacter pylori infection. S.Pb., 2013: 1-38. (in Russian)

37. Betty R. Essential medical statistics. 2nd ed. Kirkwood and Jonathan A. C. Sterne: Blackwell Science Ltd., 2003: 414-425.

38. Pimanov S.I., Makarenko E.V., Voropaeva A.V. et al. Prerequisites for Empirical Eradication Therapy in Patients With Duodenal Ulcer: Study in Belarus. Helicobacter. 2003; 8: 475.

39. Konorev M.R., Litvyakov A.M., Krylov Yu.V. et al. Chronic duodenitis associated with Helicobacter pylori. Clinical medicine. 1999; 77 (11): 49-52. (in Russian)

40. Konorev MR., Andronova TM., Matveenko ME. Use of probiotics and probiotic-based immunomodulators as adjuvant therapy for Helicobacter pylori eradication. Ter Arkh 2016; 88(12): 140148.) (in Russian)

41. Nikitushkin VD, Demina GR, Shleeva MO, Guryanova SV, Ruggiero A, Berisio R, Kaprelyants AS. A product of RpfB and RipA joint enzymatic action promotes the resuscitation of dormant mycobacteria. FEBS J. 2015 Jul;282(13):2500-11. doi: 10.1111/ febs.13292.

42. Rosenstiel P., Hellmig S., Hampe J., et al. Influence of polymorphisms in the NOD1/CARD4 and NOD2/CARD15 genes on the clinical outcome of Helicobacter pylori infection. Cell. Microbiol. 2006; 8(7): 1188-1198.

43. Claes A.K., Zhou J.Y., Philpott D.J. NOD-Like Receptors: Guardians of Intestinal Mucosal Barriers. Physiology (Bethesda). 2015; 30(3): 241-250. doi: 10.1152/physiol.00025.2014

44. Fan X.G., Yakoob J., Fan X.J., Keling P.W. Enchanced T-helper 2 Lymphocyte responses: immune mechanism of Helicobacter pylori infection. Ir. J. Med.Sci.1996;165(1):37-39.

45. Beigier-Bompadre M., Moos V., Belogolova E., et al. Modulation 
of the CD4+ T-cell response by Helicobacter pylori depends on known virulence factors and bacterial cholesterol and cholesterol

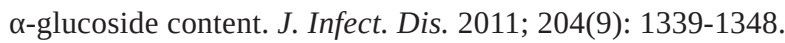

46. Konorev M.R., Konevalova N.Yu. Modern concepts of the immune system associated with the intestinal mucosa. Immunopathology, allergology, infectology. 2010; 2: 40-46.

47. Larussa T., Leone I., Suraci E., et al. Helicobacter pylori and T Helper Cells: Mechanisms of Immune Escape and Tolerance. $J$. Immunol. Res. 2015; 2015: 981328.

48. Guryanova S.V., Kozlov I.G., Meshcheryakova E.A., Alekseeva L.G., Andronova T.M. Glucosaminylmuramyl dipeptide normalizes the Th1 / Th2 balance in atopic bronchial asthma. Immunologiya. 2009; 5: 305-8. (in Russian)

49. Tong J.L., Ran Z.H., Shen J., et al. Meta-analysis: the effect of supplementation with probiotics on eradication rates and adverse events during Helicobacter pylori eradication therapy. Aliment. Pharmacol. Ther. 2007; 25(2): 155-168. doi: 10.1111/j.13652036.2006.03179.x.

50. Zou J., Dong J., Yu X. Meta-analysis: Lactobacillus containing quadruple therapy versus standard triple first-line therapy for Helicobacter pylori eradication. Helicobacter. 2009; 14(5): 97107. doi: 10.1111/j.1523-5378.2009.00716.x.

51. Sachdeva A., Nagpal J. Effect of fermented milk-based probiotic preparations on Helicobacter pylori eradication: a systematic review and meta-analysis of randomized-controlled trials. Eur. J. Gastroenterol. Hepatol. 2009; 21(1): 45-53. doi: 10.1097/ MEG.0b013e32830d0eff

52. Szajewska H., Horvath A., Piwowarczyk A. Meta-analysis: the effects of Saccharomyces boulardii supplementation on Helicobacter pylori eradication rates and side effects during treatment. Aliment. Pharmacol. Ther. 2010; 32(9): 1069-1079. doi: 10.1111/j.1365-2036.2010.04457.x

53. Wang Z.H., Gao Q.Y., Fang J.Y. Meta-analysis of the efficacy and safety of Lactobacillus-containing and Bifidobacterium-containing probiotic compound preparation in Helicobacter pylori eradication therapy. J. Clin. Gastroenterol. 2013; 47(1): 25-32. doi: 10.1097/MCG.0b013e318266f6cf

54. Zheng X., Lyu L., Mei Z. Lactobacillus-containing probiotic supplementation increases Helicobacter pylori eradication rate: evidence from a meta-analysis. Rev. Esp. Enferm. Dig. 2013; 105(8): 445-453. doi: 10.4321/S1130-01082013000800002.

55. Li S., Huang X.L., Sui J.Z. et al. Meta-analysis of randomized controlled trials on the efficacy of probiotics in Helicobacter pylori eradication therapy in children. Eur. J. Pediatr. 2014; 173(2): 153-161. doi: 10.1007/s00431-013-2220-3

56. Dang Y., Reinhardt J.D., Zhou X., Zhang G. The Effect of Probiotics Supplementation on Helicobacter pylori Eradication Rates and Side Effects during Eradication Therapy: A Meta-Analysis. PLoS One. 2014; 9(11): e111030. doi: 10.1371/journal.pone.0111030

57. Zhu R., Chen K., Zheng Y.-Y. et al. Meta-analysis of the efficacy of probiotics in Helicobacter pylori eradication therapy. World
J. Gastroenterol. 2014; 20: 18013-18021. doi: 10.3748/wjg.v20. i47.18013

58. Zhifa L.V., Wang B., Zhou X., et al. Efficacy and safety of probiotics as adjuvant agents for Helicobacter pylori infection: A meta-analysis. Exp. Ther. Med. 2015; 9(3): 707-716.

59. Zhang M.M., Qian W., Qin Y.Y. et al. Probiotics in Helicobacter pylori eradication therapy: a systematic review and meta-analysis. World J. Gastroenterol. 2015; 21(14): 4345-4357. doi: 10.3748/ wjg.v21.i14.4345

60. Lü M., Yu S., Deng J. et al. Efficacy of Probiotic Supplementation Therapy for Helicobacter pylori Eradication: A Meta-Analysis of Randomized Controlled Trials. PLoS One. 2016; 11(10): e0163743. doi: 10.1371/journal.pone.0163743

61. Lau C.S., Ward A., Chamberlain R.S. Probiotics improve the efficacy of standard triple therapy in the eradication of Helicobacter pylori: a meta-analysis. Infect. Drug Resist. 2016; 9: 275-289. doi: 10.2147/IDR.S117886

62. Shi X. et al. Efficacy and safety of probiotics in eradicating Helicobacter pylori. A network meta-analysis. Medicine (Baltimore). 2019; 98(15): e15180. doi: 10.1097/ MD.0000000000015180

63. Losurdo G., Cubisino R., Barone M. et al. Probiotic monotherapy and Helicobacter pylori eradication: A systematic review with pooled-data analysis. World J. Gastroenterol. 2018; 24(1): 139149. doi: 10.3748/wjg.v24.i1.139.

64. Bogdanov I.G., Dalev P.G., Gurevich A.I. et al. Antitumour glycopeptides from Lactobacillus bulgaricus. FEBS Lett. 1975;57: 259-261.

65. Cameron E.A.B., Bell G.D., Baldwin L., et al. Long-Term Study of Re-Infection Following Successful Eradication of Helicobacter pylori Infection. Alimentary Pharmacology \& Therapeutics. 2006; 23(9): 1355-1358.

\section{Список литературы}

1. Malfertheiner P., Megraud F., O'Morain C.A., et al. Management of Helicobacter pylori infection - the Maastricht-IV / Florence Consensus Report. Gut. 2012; 61: 646-664. doi:_10.1136/gutjnl-2012-302084

2. Malfertheiner P., Megraud F., O'Morain C.A., et al. Management of Helicobacter pylori infection - the Maastricht V/ Florence Consensus Report. Gut. 2017; 66: 6-30. doi: 10.1136/ gutjnl-2016-312288

3. Hunt R., Xiao S.D., Megraud F., et al. Helicobacter pylori in developing countries. World Gastroenterology Organisation Global Guideline. J. Gastrointestin. Liver Dis. 2011; 20(3): 299-304. doi: 10.1097/MCG.0b013e31820fb8f6

4. Marshall B.J. Warren J.R. Unidentified curved bacilli on gastric ileum in active chronic gastritis Lancet 1983; 1: 1273-1275.

5. Sugano K., Tack J., Kuiperset E.J. et al. Kyoto global consensus report on Helicobacter pylori gastritis. Gut. 2015; 64(9): 1353-1367. doi: 10.1136/gutjnl-2015-309252 
6. Hopkins R.J. Current FDA-approved treatments for Helicobacter pylori and the FDA approval process. Gastroenterology. 1997; 113(6, Suppl): S126-30.

7. Ивашкин В.Т., Маев И.В., Лапина Т.Л. и др. Клинические рекомендации Российской гастроэнтерологической ассоциации по диагностике и лечению инфекции Helicobacter pylori у взрослых. Рос. ж. гастроэнтерол. гепатол. колопроктол 2018; 28(1): 55-70.

8. Минушкин О.Н., Осокина А.П., Шулешова А.Г. и др. Отдаленные результаты успешной эрадикации Helicobacter pylori у больных язвенной болезнью двенадцатиперстной кишки. Кремлевская медицина. Клинический вестник. 2012; 1: 123-126.

9. Бураков И.И. Результаты долгосрочного наблюдения за больными язвенной болезнью, ассоциированной с Helicobacter pylori, после эрадикации микроорганизма. Эксперим. и клин. гастроэнтерол. 2002; 3: 45-48.

10. Hu Y., Wan J.-H., Li X.-Y. et al. Systematic review with meta-analysis: the global recurrence rate of Helicobacter pylori. Aliment. Pharmacol. Ther. 2017; 46: 773-779. doi: 10.1111/apt.14319

11. Lionetti E., Indrio F., Pavone L., et al. Role of probiotics in pediatric patients with Helicobacter pylori infection: a comprehensive review of the literature. Helicobacter. 2010; 15(2): 79-87. doi: 10.1111/j.1523-5378.2009.00743.x

12. O’Connor A. et al. Treatment of Helicobacter pylori infection 2019. Helicobacter 2019; 24(Suppl.1): e12640. doi: 10.1111/ hel.12640

13. Gill H.H., Prasad J. Probiotics, immunomodulation and health benefits. Adv. Exp. Med. Biol. 2008; 606: 423-454.

14. Пинегин Б.В., Андронова Т.М. Некоторые теоретические и практические вопросы клинического применения иммуномодулятора ликопида. Иммунология. 1998; 4: 60-63.

15. Гурьянова С.В., Хаитов Р.М. Глюкозаминилмурамилдипептид - ГМДП: воздействие на мукозальный иммунитет (к вопросу иммунотерапии и иммунопрофилактики). Иммунология. 2020, 41 (2): 174-183. DOI: 10.33029/02064952-2020-41-2-174-183

16. Meshcheryakova E., Makarov E., Philpott D., Andronova T., Ivanov $V$. Evidence for correlation between the intensities of adjuvant effects and NOD2 activation by monomeric, dimeric and lipophilic derivatives of $\mathrm{N}$-acetylglucosaminy $\mathrm{N}$-acetylmuramyl peptides. Vaccine. 2007; 25: 4515-20.

17. Laman A.G., Lathe R., Shepelyakovskaya A.O., Gartseva A., Brovko F.A., Guryanova S., Alekseeva L., Meshcheryakova E.A., Ivanov V.T. Muramyl peptides activate innate immunity conjointly via YB1 and NOD2. Innate Immunity. 2016. T. 22. № 8. C. 666673. DOI: $10.1177 / 1753425916668982$

18. Крашенинников А.Е., Матвеев А.В., Андронова Т.М., Гурьянова С.В., Шилова Н.В., Козлов И.Г. Безопасность применения препарата «Ликопид®» по мнению врачей различных специальностей. Пермский медицинский журнал.
2019. T. 36. № 2. C. 81-92. DOI: 10.17816/pmj36281-92

19. Guryanova S.V. Antibiotic resistance: ligands of innate immunity take the challenge. Allergy. 2018. T. 73. № S105. C. 581.

20. Абрамашвили Ю.Г., Колесникова Н.В., Борисова О.Ю., Гурьянова С.В. Оптимизация низкомолекулярным биорегулятором бактериального происхождения терапии кондиломатоза // Вестник Российского университета дружбы народов. Серия: Медицина. 2020. Т. 24. № 2. С. 163-167. DOI:10.22363/2313-0245-2020-24-2-163-167

21. Козлов И.Г., Гурьянова С.В. , Колесникова Н.В., Андронова T.M. Мурамилпептиды и другие агонисты рецепторов врожденного иммунитета в комплексной терапии аллергических заболеваний. Российский аллергологический журнал. 2015; 5: 59-67.

22. Козлов И.Г., Колесникова Н.В., Воронина Е.В., Гурьянова C.В., Андронова T.M. Глюкозаминилмурамилдипептид и другие агонисты рецепторов врожденного иммунитета в патогенетической терапии аллергических заболеваний. Аллергология и иммунология. 2013; 14 (4): 281-7.

23. Guryanova S., Udzhukhu V., Kubylinsky A. Pathogenetic therapy of psoriasis by muramyl peptide. Frontiers in Immunology. 2019. T. 10. № JUN. C. 1275. DOI: 10.3389/fimmu.2019.01275

24. Манапова Э.Р., Фазылов В.Х., Гурьянова С.В. Цитопении и их коррекция при противовирусной терапии хронического гепатита С у пациентов с генотипом 1. Вопросы вирусологии. 2017; 62 (4): 174-8.

25. Гурьянова С.В., Борисова О.Ю., Колесникова Н.В., Лежава Н.Л., Козлов И.Г., Гудима Г.О. Влияние мурамилпептида на микробный состав микрофлоры ротовой полости. Иммунология. 2019; 40 (6): 34-40. DOI: 10.24411/0206-49522019-16005

26. Конорев М.Р. Влияние ликопида на персистенцию Helicobacter pylori в слизистой оболочке желудка больных с хроническими гастритами. Иммунопатология, аллергология, инфектология. 2004; 2: 33-34.

27. Конорев М.P. Применение иммуномодулятора N-ацетил-глюкозаминил-N-ацетилмурамилдипептида при проведении антихеликобактерной тройной терапии. Терапевтический архив. 2012; 12: 65-69.

28. Tytgat G.N. The Sydney system, endoscopic division: endoscopic appearance in gastritis. J. Gastroenterol. Hepatol. 1991; 6(3): 223-234.

29. Аруин Л.И., Григорьев П.Я., Исаков В.А., Яковенко Э.П. Хронический гастрит. Амстердам, 1993: 3-362.

30. Конорев М.Р., Литвяков А.М., Крылов Ю.В., Матвеенко М.Е. Хронический дуоденит. Мн: ООО «ДокторДизайн», 2003.

31. Price A.B. The Sydney system: Histological division. J. Gastroenterol. Hepatol. 1991; 6(3): 209-222.

32. Dixon M. et al. Classification and grading of gastritis. Am. J. Surg. Pathol. 1996; 20: 1161-1181.

33. Kido M., Tanaka J., Aoki N., et al. Helicobacter pylori promotes 
the production of thymic stromal lymphopoietin by gastric epithelial cells and induces dendritic cell-mediated inflammatory $\mathrm{Th}_{2}$ responses. Infect. Immun. 2010; 78(1): 108-114.

34. Chang C., Pan S., Lien Gi., et al. Investigation of the extent of gastric metaplasia in the duodenal bulb by using methylene blue staining. J.Gastroenterol.Hepatol. 2001; 16(7): 729-739.

35. Аруин Л.И., Капуллер Л.Л., Исаков В.А. Морфологическая диагностика болезней желудка и кишечника. М.: Триада-Х, 1998: 13-496.

36. Конорев М.Р., Матвеенко М.Е., Крылов А.Ю. и др. Быстрый уреазный тест Хелпил для диагностики инфекции Helicobacter pylori. С.-Пб., 2013: 1-38.

37. Betty R. Essential medical statistics. 2nd ed. Kirkwood and Jonathan A. C. Sterne: Blackwell Science Ltd., 2003: 414-425.

38. Pimanov S.I., Makarenko E.V., Voropaeva A.V. et al. Prerequisites for Empirical Eradication Therapy in Patients With Duodenal Ulcer: Study in Belarus. Helicobacter. 2003; 8: 475.

39. Конорев М.Р., Литвяков А.М., Крылов Ю.В. и др. Хронический дуоденит, связанный с Helicobacter pylori. Клиническая медицина. 1999; 77(11): 49-52.

40. Конорев М.Р., Андронова Т.М., Матвеенко М.Е. Использование пробиотиков и иммуномодуляторов на их основе в качестве адъювантной терапии при проведении эрадикации Helicobacter pylori. Терапевтический архив. 2016; 12: 140-148. doi: 10.17116/terarkh20168812140-148

41. Nikitushkin V.D., Demina G.R., Shleeva M.O., Guryanova S.V., Ruggiero A., Berisio R., Kaprelyants A.S. A product of RpfB and RipA joint enzymatic action promotes the resuscitation of dormant mycobacteria. FEBS J. 2015 Jul;282(13):2500-11. doi: 10.1111/febs.13292.

42. Rosenstiel P., Hellmig S., Hampe J., et al. Influence of polymorphisms in the NOD1/CARD4 and NOD2/CARD15 genes on the clinical outcome of Helicobacter pylori infection. Cell. Microbiol. 2006; 8(7): 1188-1198.

43. Claes A.K., Zhou J.Y., Philpott D.J. NOD-Like Receptors: Guardians of Intestinal Mucosal Barriers. Physiology (Bethesda). 2015; 30(3): 241-250. doi: 10.1152/physiol.00025.2014

44. Fan X.G., Yakoob J., Fan X.J., Keling P.W. Enchanced T-helper 2 Lymphocyte responses: immune mechanism of Helicobacter pylori infection. Ir. J. Med.Sci.1996;165(1):37-39.

45. Beigier-Bompadre M., Moos V., Belogolova E., et al. Modulation of the CD4+ T-cell response by Helicobacter pylori depends on known virulence factors and bacterial cholesterol and cholesterol $\alpha$-glucoside content. J. Infect. Dis. 2011; 204(9): 1339-1348.

46. Конорев М.Р., Коневалова Н.Ю. Современные представления об иммунной системе ассоциированной со слизистой оболочкой кишечника. Иммунопатология, аллергология, инфектология. 2010; 2: 40-46.

47. Larussa T., Leone I., Suraci E., et al. Helicobacter pylori and T Helper Cells: Mechanisms of Immune Escape and Tolerance. J. Immunol. Res. 2015; 2015: 981328.
48. Гурьянова С.В., Козлов И.Г., Мещерякова Е.А., Алексеева Л.Г., Андронова Т.М. Глюкозаминилмурамилдипептид нормализует баланс Th1/Th2 при атопической бронхиальной астме. Иммунология. 2009; 5: 305-8.

49. Tong J.L., Ran Z.H., Shen J., et al. Meta-analysis: the effect of supplementation with probiotics on eradication rates and adverse events during Helicobacter pylori eradication therapy. Aliment. Pharmacol. Ther. 2007; 25(2): 155-168. doi: 10.1111/j.13652036.2006.03179.x.

50. Z Zou J., Dong J., Yu X. Meta-analysis: Lactobacillus containing quadruple therapy versus standard triple first-line therapy for Helicobacter pylori eradication. Helicobacter. 2009; 14(5): 97107. doi: 10.1111/j.1523-5378.2009.00716.x.

51. Sachdeva A., Nagpal J. Effect of fermented milk-based probiotic preparations on Helicobacter pylori eradication: a systematic review and meta-analysis of randomized-controlled trials. Eur. J. Gastroenterol. Hepatol. 2009; 21(1): 45-53. doi: 10.1097/ MEG.0b013e32830d0eff

52. Szajewska H., Horvath A., Piwowarczyk A. Meta-analysis: the effects of Saccharomyces boulardii supplementation on Helicobacter pylori eradication rates and side effects during treatment. Aliment. Pharmacol. Ther. 2010; 32(9): 1069-1079. doi: 10.1111/j.13652036.2010.04457.x

53. Wang Z.H., Gao Q.Y., Fang J.Y. Meta-analysis of the efficacy and safety of Lactobacillus-containing and Bifidobacterium-containing probiotic compound preparation in Helicobacter pylori eradication therapy. J. Clin. Gastroenterol. 2013; 47(1): 25-32. doi: 10.1097/ MCG.0b013e318266f6cf

54. Zheng X., Lyu L., Mei Z. Lactobacillus-containing probiotic supplementation increases Helicobacter pylori eradication rate: evidence from a meta-analysis. Rev. Esp. Enferm. Dig. 2013; 105(8): 445-453. doi: 10.4321/S1130-01082013000800002.

55. Li S., Huang X.L., Sui J.Z. et al. Meta-analysis of randomized controlled trials on the efficacy of probiotics in Helicobacter pylori eradication therapy in children. Eur. J. Pediatr. 2014; 173(2): 153-161. doi: 10.1007/s00431-013-2220-3

56. Dang Y., Reinhardt J.D., Zhou X., Zhang G. The Effect of Probiotics Supplementation on Helicobacter pylori Eradication Rates and Side Effects during Eradication Therapy: A MetaAnalysis. PLoS One. 2014; 9(11): e111030. doi: 10.1371/journal. pone. 0111030

57. Zhu R., Chen K., Zheng Y.-Y. et al. Meta-analysis of the efficacy of probiotics in Helicobacter pylori eradication therapy. World J. Gastroenterol. 2014; 20: 18013-18021. doi: 10.3748/wjg.v20.i47.18013

58. Zhifa L.V., Wang B., Zhou X., et al. Efficacy and safety of probiotics as adjuvant agents for Helicobacter pylori infection: A meta-analysis. Exp. Ther. Med. 2015; 9(3): 707-716.

59. Zhang M.M., Qian W., Qin Y.Y. et al. Probiotics in Helicobacter pylori eradication therapy: a systematic review and meta-analysis. World J. Gastroenterol. 2015; 21(14): 4345-4357. doi: 10.3748/ wjg.v21.i14.4345 
60. Lü M., Yu S., Deng J. et al. Efficacy of Probiotic Supplementation Therapy for Helicobacter pylori Eradication: A Meta-Analysis of Randomized Controlled Trials. PLoS One. 2016; 11(10): e0163743. doi: 10.1371/journal.pone.0163743

61. Lau C.S., Ward A., Chamberlain R.S. Probiotics improve the efficacy of standard triple therapy in the eradication of Helicobacter pylori: a meta-analysis. Infect. Drug Resist. 2016; 9: 275-289. doi: $10.2147 /$ IDR.S117886

62. Shi $X$. et al. Efficacy and safety of probiotics in eradicating Helicobacter pylori. A network meta-analysis. Medicine (Baltimore). 2019; 98(15): e15180. doi: 10.1097/ MD.0000000000015180

63. Losurdo G., Cubisino R., Barone M. et al. Probiotic monotherapy and Helicobacter pylori eradication: A systematic review with pooled-data analysis. World J. Gastroenterol. 2018; 24(1): 139149. doi: 10.3748/wjg.v24.i1.139.

64. Bogdanov I.G., Dalev P.G., Gurevich A.I. et al. Antitumour glycopeptides from Lactobacillus bulgaricus. FEBS Lett. 1975;57: 259-261.

65. Cameron E.A.B., Bell G.D., Baldwin L., et al. Long-Term Study of Re-Infection Following Successful Eradication of Helicobacter pylori Infection. Alimentary Pharmacology \& Therapeutics. 2006; 23(9): 1355-1358.

Ответственный за переписку: Гурьянова Светлана Владимировна - канд. биол. наук, доцент кафедры биологии и общей генетики Медицинского института Российский университет дружбы народов, 117998, ул. Миклухо-Маклая, 10, Москва, Россия. Email: svgur@mail.ru

SPINкод: 6722-8695, ORCID ID: orcid.org/0000-0001-6186-2462

Corresponding Author: Guryanova Svetlana V. - PhD, Associate Professor of the Department of Biology, Medical Institute of the Peoples’ Friendship University of Russia, 117198, Miklukho-Maklaya str., 10, Moscow, Russia. Email: svgur@mail.ru

ORCID ID: orcid.org/0000-0001-6186-2462 